\title{
National narration and Politics of Memory in post-socialist Georgia
}

\author{
Salome Dundua ${ }^{1}$ \\ Tamar Karaia ${ }^{2}$ \\ Zviad Abashidze ${ }^{3}$
}

\begin{abstract}
The article is dedicated to analyse the politics of so called "historical memory" during the state-building and nation-building process in post-socialist Georgia After the Rose Revolution 2003, the new government that aimed at building the "new Georgia," implementing radical changes in many key spheres, including institutions, readdressing the totalitarian past, faced number of problematic manifestations in political and cultural life in this post-Soviet country. The "politics of memory" became one of the key factors of reconstructing of "new, democratic, western Georgia". This process can be evaluated as leading toward state nationalism. Analyzing the politics of memory, symbolism is the most notable attitude and that is why former President Mikheil Saakashvili used commemorative ceremonies continuously. The authors argue in favour of approach, that the so called "memory politics" is the integral part of one's legitimacy building, but at the same time, it can be used as tool for reconsidering of Polity's future and mobilization of population under the "citizenship" umbrella towards the strong loyalty to the actual and future state-building.
\end{abstract}

Key words: Memory, Politics, Democracy, Nation Building, Post-communism

Interest in memory studies increased in the wake of WWII and Holocaust. Additionally, when the soviet system collapsed it became another focal point, which stimulates research in this field. Furthermore, "memory boom" become a commonly used expression.

The reason is simple: after the collapse of the soviet empire, former soviet republics started building their statehood. Moreover, the consolidation of the nation around new ideals and formation of new identities, which would confront to the soviet one, made by the soviet system, was the main challenge of this process. While creating new collective memory politicians re-interpreted their ${ }^{1}$ Salome Dundua, Ph.D in Political Science; Associated Professor. Ivane Javakhishvili Tbilisi State University, Faculty of Social and Political Sciences, Department of Political Science. 1. Chavchavadze ave. 0179. Tbilisi. Georgia. E-mail: salomedundua@yahoo.com.

2 Tamar Karaia, Ph.D in Political Science, Assistant Professor. Ivane Javakhishvili Tbilisi State University, Faculty of Social and Political Sciences, Department of Political Science, 1. Chavchavadze ave. 0179. Tbilisi. Georgia.E-mail: tamar.karaia@tsu.ge.

${ }^{3}$ Zviad Abashidze, Ph.D in Political Science, Assistant Professor. Ivane Javakhishvili Tbilisi State University, Faculty of Social and Political Sciences, Department of Political Science. 1. Chavchavadze ave. 0179. Tbilisi. Georgia. E-mail: Zviad.abashidze@ tsu.ge. 
national histories, they re-write history textbooks, invented new heroes and enemies, established ceremonies etc. Remembering and forgetting become general trends of politics of memory accordingly.

From the point of view of social constructionist theory, both identity and memory should be analysed as a dynamic process, and as a result, society receives changed values, goals and interests. Collective memory is an indicator of how society perceives "we" and "others", which themselves influence priorities and the decisions of society. Involving memory in the political discourse we can discuss "official politics of memory", which uses different strategies forming public opinion about historical events.

In Post-Socialist Georgia, history and Historical narrations are one of the cornerstones of modern understanding of being a "Georgian" and therefore, those narrations have been usually used by the Georgian authorities in construction of legitimacy. The different historical periods have been differently perceived by public and thus it must be analysed through the stages of such perceptions. Those perceptions can be divided into three main directions, which are crucial for understanding of modern process of "politics of memory". These directions are:

1 Role of past historical narrations;

2 The consideration of the history and role of church in this process;

3. Activation of politics of memory and leading to establish state nationalism;

\section{GEORGIA'S IDENTITY THROUGH THE HISTORICAL PERSPECTIVES}

\subsection{Medieval and Modern narratives of "Georgia"}

Social scientist are generally agreed that the process construction of ones owns group identity is held under conditions of visa a vie relationships with "others". The image of "others" is the cornerstone of the strengthening of one's own identity. The approach is especially adequate to the construction of ones "national identity", who is intending to defend its "authencity" from "others". Therefore as it justly accepted in social sciences, the differentiation between "we" and "others" is crucial in process of understanding the spirit and sense of Nationhood.

It is broadly accepted as in scholars as in public in Georgia, that Georgians are one of the oldest cultural nations in the world, who through it's difficult historical developments used to try to defend the "civilized" space from the very east boundaries from barbarians. Such difficulties were caused by Georgia's geopolitical situation, by means of borderline, intersection of European and 
Eastern civilization. Therefore, the image of Georgians centuries struggle for independence and Christianity against the "uncivilized people" (Turks, Persians, Mongols, Arabs, Russians and etc.) broadly shaped their identity and sense of distinctiveness from 'others'. As it is traditionally accepted by Georgian historians, the history of Georgian statehood has at least 3-millenniua old tradition.

The adoption of Christianity as official religion in 326 and Feudal history in general have become the cornerstone of Georgian narrative of national mythology. After the end of Arab domination, since the $8^{\text {th }}$ century, there appeared several new Georgian kingdoms and principalities, among which gradually TaoKlarjeti Kingdom took a hegemony (the biggest part of which now is a part of Turkey), where within the strong monastery life in 10th century was constructed the medieval paradigm of Georgia by the Hagiographic author Giorgi Merchule: "Georgia is consisted of lands where the Christian mesas and every preach are exercised in Georgian". ${ }^{4}$ (Merchule, 2000).

Gradually in 11 century, during the times the first centralized Georgian feudal state appeared, the modern name of Georgia in Georgian was acquired "SAQARTVELO".

11-13 centuries are the "golden age" of Georgian history. By that time Georgia became a Pan-Caucasian super power, with flourishing and brilliant secular medieval culture, sometimes called as "first breath of Renaissance" 5 (Davies, 1996).

The ancient Sumerian word "Eri", the Georgian synonym of Latin "Natio" historically has had a little bit different meaning than its Latin counterpart. The Latin "Natio" during the Middle Ages was the equal of the Greek "genes", meant "origination or birth". It only in modern era adopted the meaning of political community.

Firstly in Georgian "Eri" often was associated with language community (for instance, we can trace the facts in first translations of Bible), but primarily under it, the secular community was implied, regardless of ethnic or other origins of it members. During the mentioned 'Golden age", the "Eri" became a term of common secular identity; regardless it was nobility, peasants and etc (excluding King).

There were two main ways of membership in Eri or to be a "Georgian" in general: First to be a subject of the King (who represents the source of political identity based on vertical lines in whole the medieval Europe) and to convert into the Orthodox Christianity. Orthodox Christianity along with statehood had an important role in the process of constructing the Georgian identity. In short, we ${ }^{4}$ Merchule G. (2000) Life and Citizenship of Grigol Khantsteli”. Tbilisi (in Georgian) (p.12)

${ }^{5}$ Davies N. (1996) Europe, a History, Oxford University Press, p. 335 
have to say that in general the Christianity broadly shaped the Georgian culture and identity. Therefore, traditionally to fight for Christendom, meant to fight to preserving the Georgian identity.

Such a tradition remained in Georgia until the beginning the 19-century, the period of Russian domination.

Russian empire deliberately abolished the local Georgian political institutions and traditions and shaped it as a province of the huge empire and put under the process of Russification. The notion "Georgia" as a political or cultural term was completely cancelled from the vocabulary. The Independence Church of Georgia along with statehood was abolished in 1811 and subordinated to the Holy Synod of Russia. In general Georgia became an organic part of Russian autocracy and bureaucratic government.

Since this period in Georgia was being originated so called Liberal nationalism, the main representatives of which are the Georgian intellectuals from $60^{\text {th }}$ of 19 century, leaded by famous Georgian Intellectual and public figure Ilia Chavchavadze.

Unlike the medieval tradition, Ilia Chavchavadze tried to formulate the new view of Georgia and constructed the kind of new paradigm of Georgia: "Mamuli, Ena, Sartsmunoeba', "Fatherland, Language, Faith". According to the Leibnizian tradition, for Ilia "nation" became a movement from past through present to future, in other words, 'nation' was an above-mentioned "trans-generational responsibility". Ilia followingly formulated the concept of "nation": "Nation is a community shaped by history with common will and contribution.... the decline of the nation starts at the period when the nation forgets about his past." For Ilia as well as for other intellectuals from the given period, especially vital importance had a defence and revival of language and the rediscovery of Georgian history in order to construct the ground for future independence Georgian state.

Little bit latter, the leader and the founder of Social-Federalist Party in Georgia, Archil Jorjadze according to the given tradition formulated the understanding of the "nation" as "common ground of movement".

As a result of collapse of Romanovs Empire, the first precedence of the modern nation-state in Georgia is the period from 1918-1921. The Constitution of first democratic republic declared the "nation" as the only source of legitimacy, regardless the fact of countries cultural diversity. The Constitution guaranteed civil and political liberties of the citizens including ethnic groups' rights, permitting them to use their language and other cultural ties publicly, including the Court and Parliament. The firstly, Georgian Republic became a unitary-decentralized state having two autonomous formations within the state borders (Abkhazia and Muslim populated part). But, as an irony of the history, 
the Constitution had been working only for four days, because of the Bolsheviks' invasion and abolishing the independence of the country.

\subsection{The Soviet legacy}

After the Bolshevik occupation, Georgia along with most of the countries of former Romanovs' empire forcefully became a member of Soviet totalitarian system, of the new grand political project of "social justice" and "internationalism". Along with other wrong principles, one of the main interesting characters of the USSR was the so-called "national question".

Bolsheviks secure in their faith in Marx's assertion that "national differences and antagonisms between people are vanishing gradually from day to day" and the supremacy of the proletariat will cause them to vanish still fast. ${ }^{6}$ (Sunny, 2001). In 1916 pamphlet, "socialist revolution and national self-determination" Lenin admitted the right of national self-determination against the empires. According to his views, class interests are standing above the national ones ${ }^{7}$ (Sakva, 1989).

But the main ideological base of soviet nationality policy became a Stalin's famous work "Marxism and national question" where the whole formula of soviet understanding of nations or nationality is given. According to Stalin's definition, the "nation is coherent community of people, originated on base of common language, territory, economy and psychical, spiritual make up, which is articulated in culture" ${ }^{8}$ (Сталин, 1953).

According to these principles, the whole soviet policy of nation-building was founded on principles of "titular nation" and "politization of ethnicity" which in its turn became a cornerstone of soviet ethno-federalism. According to Stalin's understanding the 'nation' and 'nationality' were formed the formally independent Republics of USSR in 1922. As Richard Pipes notes 'Soviet Russia became the first modern state to place the national principles at the base of its federal structure' ${ }^{9}$ (Pipes, 1954).

The soviet political project in many sides was the first experience in the history grounded strongly on presence of ethnic categories in politics. For it, the process of formation of sense of solidarity among the different segments of the society by means of civic coexistence and civic integration had a less importance. Rather

${ }^{6}$ Sunny R. (2001), State-building and nation-making / The Russian Revolution, edited by Martin A. Miler, Blackwell Publisher, p.239

${ }^{7}$ Sakva R. (1989) Soviet Politics, an introduction, Rutledge, London and New York, p.296

${ }^{8}$ Сталин И.Б., (1953) Марксизм и национальный вопрос.//Сочинения. Тбилиси, р.22

${ }^{9}$ Pipes R. (1954) the Formation of the Soviet Union: Communism and Nationalism 1917-1923, Harvard University Press, p. 65 
it was aiming at forming the new type of person, which sometimes is called as Homo Sovieticus. As Richard Sakva correctly points 'Concept of new Soviet person was promoted as a supranational entity whose loyalty to the socialist commonwealth would take precedence over ethnic affiliation.

To sum up the meaning of soviet nationality policy, we can notice that in reality under the officially declared social egalitarianism conditions, where the existence of antagonist social classes were rejected, the ethnic groups or nationalities took a meaning and function of social classes. As we pointed out above, the process of articulation and aggregation of social interests were provided by means of ethnic representation, regardless of their real social background. Therefore, the ethnic groups became principal target groups in the process of gaining of political power or social prestige. In other words, the new project of Homo Sovieticus strongly was based on new social stratification policy, where the social groups' place or interests were gained by ethnic groups or 'nationalities'.

Therefore the membership in given ethnic affiliation firstly meant the membership in some political or social grouping. Obvious, that such kind of endeavour of founder 'fathers' of soviet totalitarianism were using during the power manipulations and strengthening the democratic centralism, on which the people of different nationalities did not consider. Ethnicity or nationality question turned out as the most ethnic components, but on religious ones.

Such kind of legacy get the Georgia from the soviet experience and if we consider those deeply, then it will not be a strange the origination of regional conflicts based on ethnic affiliations.

\subsection{Ethnicity in political agenda: problems of post-soviet nation-building}

During the 1988-89 on a wave of new soviet politics of 'glasnost' and 'perestroika' the anti-Soviet movements leaded by dissidents came into strength in Georgia. The main aim of the anticommunism in Georgia was to use right of secession provided by soviet constitution and gain the independence.

The notion of 'sovereignty' in anti-Soviet organizations programs primarily implied the 'historical right' for national self-determination and revival the Democratic Republic abolished by the Bolsheviks in 1921. To rebuild such kind of 'sovereignty' became a base of anti-Soviet movements. Therefore in views of dissidents the 'sovereignty' primarily used as 'historical right' for independence, but not 'national sovereignty' as a right of 'demos' to form the democratic polity based on free political participation. Of course the ideas of free participation and democracy were also assumed, but firstly they were aiming to gain the independence. 
As a result of strong anti-Soviet aspirations, in $28^{\text {th }}$ of October of 1990 in Georgia held the first democratic, multiparty elections. In power came the former dissidents, coalition of 'round table' leaded by famous Georgian dissident and public figure Zviad Gamsakhurdia.

The political project of Gamsakhurdia was to form the unitary nation-state. The first democratically elected government rejected the traditional French political project of liberal assimilation. The traditional, Georgian politics of medieval tolerance remained the place into the political agenda, in which the rights of ethnic minorities for self-cultural development was guaranteed. But according to the new governmental policies, the role and function of Georgian language was promoting. Such kind of promotion of 'Georgianizms', sometimes were adopted as threat by the some ethnic minorities and therefore, often they were claiming for discrimination and oppression by the new government.

In 31th of March of 1991 the referendum for independence held. $98 \%$ of the population voted for independence. On base of the referendum results, Georgian Supreme Soviet in 9Th of April declared the independence of the country. According to the independence declaration, 'Georgian nation' was admitted as bearer of sovereignty, who 'expressed' his ' historical right' for formation of independence state on a base of toleration and other democratic principles. Here the notion of 'nation' can be understood in two ways: firstly as a manifestation of soviet concept of 'ethno-nation' and secondly 'nation' as a political community. In spite of ethnic categories presence in such perception of 'nation', it can be observed there some elements of citizenship. The declaration directly indicates that the 'bearer of sovereignty is a nation' based on a right on equal political participation of citizens, regardless their group belongness or identity. In this case, we can note the first precedence in post-soviet stage in Georgia of civil elements entering in strong ethicized politics of identity.

The first democratic post-soviet government adopted the special declaration admitting the rights of ethnic minorities and guaranteeing their protection. But Gamsakhurdia was strong anti-Communist who did not agreed on a reconstruction of new form of USSR, that's why still dominating soviet machinery of secret service intended to make from Gamsakhurdia the image of strong 'nationalist' and 'chauvinist'. Gamsakhurdia could not reach the international admission. As justly points Bruno Coppiters; 'Rejection the first government of Georgia by the western countries, primarily was determined by the hope on probable democratization of soviet ethno-federalism' ${ }^{10}$ (Коппитерс, 1999).

After the coup d'etat of 1991 22th of December-1996 $6^{\text {th }}$ of January, former

${ }^{10}$ Коппитерс Б. (1999) «Этнофедерализм и политика в области строительства гражданского государства. (Поиски альтернативов для Грузии и Абхазии) Практика федерализма (Общая редакция Б. Коппитерс, Д.Дарчиашвили, Н. Акаба) Весь мир, Москва, pp. 343-344 
minister of foreign affairs of USSR Eduard Shevardnadze came to power. As a result of power changes, in Abkhazia were sent (which has never done by Gamsakhurdia) the Georgian unorganized troops, officially to defend the railways. As a result, officially Abkhazian political elite grouping, by helping and inspiration of Russian political elite used the soviet Abkhazian Constitution according to which Abkhazia is an independent state and bloody war broke up. In 1993 Georgian Armed Forces were defeated; the local Georgian population was totally displaced from their own houses, as enemies of 'Abkhazian nation'.

Shortly, Shverdnadze's period (1992-2003) has been characterized as "failed state", where the whole political system was based on patron-clientelism, corruption and destruction of political institutions. Therefore, practically, it is impossible to indicate to any reflected policies to understand the idea of construction of "historical memory" from the given period. It was just permanent struggle for power among the different corrupted/criminal and para-military groups. Shevardnadze, by the late $90^{\text {th }}$ managed to stabilize the public-political sphere on certain extends, but he was mostly impotent to construct any effective political institutions, as shelter of normal political processes.

\section{OBSTACLES FOR OF SECULAR IDENTITY}

In modern, secularized world's democratic and partly democratic states (with a few exceptions) the sphere of politics and religion are clearly separated from each other on the declared and legislative levels. Generally, secularization is the process when religious though, practice and organization lose their social impact and meanings. However, in many countries religion still plays (or tries to play) quite important role in formation of public-political space's agenda. There are numerous examples from different religious institutions (with various dosage and forms). When scientists discuss about issues of religion and politics, some of them consider as the main problem the relationship between democracy and Muslim religion. Therefore, we cannot ignore the fact that the religious institutions activities, in particular the Christian churches (the explicit examples of which is USA and Poland) even in western developed countries are moderately high. On the other hand, after failure of the communist system in post-communist countries there are quite numerous references to religion, as well as activities of religious institutions in public-political spaces. Part of the scientists is eagerly talking even about the failure of the idea of secularization and this fact indicates the requirement of the establishment of the qualitatively new type of relationship between the state and religious institutions. 
As American political scientist Jean Bethke Elshtain notes ${ }^{11}$ (Elshtain, 2009):

"The hypothesis of secularization has failed and this failure was spectacular one. Now we need to look for new paradigm, which will help us understand the complexities of the relationship between religion and democracy".

Similar to some post-communist countries, in Georgia the role of Church, as an important public institution, has become obvious after the collapse of soviet system.

Church-state relation over the last two decades remains in Georgia as one of the actual themes, which has its determining factors, among which, in our opinion, the most important things are:

1) Public authorities often do not enjoy the same degree of legitimacy like a church, which has great influence on public opinion.

2) In many cases, the church views are more taken into consideration and valuable to society than the government's one.

3) The scepticism that is about politics does not exist (or exists less) about church; criticism about the Church rarely happens and if it happens, is denounced by the majority of society.

Despite the fact that Georgia has achieved some success in building a democratic state, democratic institutions are still weak in the country. In the condition of absence of trust towards political institutions on one hand, and weakness of these institutions on the other hand, it is becoming evident (especially the last time), that the most authoritative institution, to which are appealing all political actors is gradually getting the Orthodox Church of Georgia.

Georgia has traditionally been an Orthodox political space. Accordingly it was not unusual for Georgia's political reality to use Orthodoxy as the mean to achieve some political purposes. But recently in time of some latest significant political events, so called low level of economic development and heavy social background, when still weak civil society institutions cannot guarantee the strengthening of democratic consciousness among the citizens and transformation of society into one civil unit, it seems like that Orthodox Church of Georgia plays (or sometimes political actors themselves "delegated" to it) civil societies institution's very important role and functions.

According to all kind studies, the degree of legitimacy of Georgian Orthodox Church is incomparable higher in comparison of other formal institutions. For instance: according to survey of 2012 by German based sociological and research institution of "Forsa" $89 \%$ of respondent believe in Georgian Orthodox Church, 74\% - in Georgian Army and only 30\% in Court system.

${ }^{11}$ Elshtain J. B., (April 2009) Religion and Democracy, Journal of Democracy, Volume 20, Number 2, pp. 15 
Because of such huge degree of legitimacy of Orthodox Church, majority of Georgian political actors frequently intend to be closer with Church to get higher degree of legitimacy and support in public-political sphere. In the wake of some political events, rather difficult social problems and not a high temp of economic growth is coming evident that civil society's institutions cannot equally ensure civic activation of the most of population and transformation of society into one whole civic space.

While civic and political institutions are on a way of gaining proper legitimacy, for a large part of the population traditional Orthodox Church remains the most attractive and trusted institution. The church seems to be the institution, which largely determines the framework for societal relations and, more importantly, plays a great role in the formation of national identity. Consequently, we can consider the Orthodox Church not only as the institution formatting religious beliefs, private life and moral, but also as strong socio-political actor which sometimes appears as a competitor of state.

Accordingly, not surprisingly, we can see the Orthodox Church as a one of the decisive stakeholders in Georgian social and political life. The Church, by using the different channels of articulations and aggregations (Patriarch's Epistles, preaches, special addresses connected with current issues and concrete initiatives with ban of abortion, projects of development of agriculture, offering an alternative way of sentence to people deprived of liberty Churches and Monasteries, etc.) not only rarely influence over the formation of public agenda, but often itself have some initiatives too.

In activities toward this direction church frequently applies to the method of memory politics - as the revival of the past experiences and building modern state on this basis. Using the past as the tool of giving experience for modernity we can outline some main directions:

1. State thinking - dignity, freedom, responsibility. Must be interconnected chain - me, you, and we - For each other and all of us for Georgia. First, the state has to do some steps towards this direction and the Church will support the state. As the examples of realization and inculcation of given ideals because of their made use those of Georgian historian heroes, kings and public men, who were declared as saints by the Church for their contribution to motherland.

"To serve fatherland with true faith - is one of the main contributions; Exactly with these marks - Tzotne Dadiani, Demetre Tavdadebuli, Eqvitime Takhaishvili and others are canonized as saints by the Church"( Easter Epistle of Patriarch 2005) - is said in the 2005 Easter Epistle of Patriarch of Georgia. 
2. To use historical heroes as the means of strengthening tolerance: Georgia has traditionally been a multi-religious and multi-ethnic society where different ethnic and religious groups have to peacefully coexist with each other. However, it is paradoxical that different groups that lived in Georgia beside each other for centuries know a little or nothing about each other's cultural values and achievements. The perception of each other's culture happens on the ground of prejudices and stereotypes; According to this it is difficult to call modern Georgia ethno - confessionally integrated and consolidated state. One of its main objectives is the creation of such public space where all of the ethno-confessional groups living in the state would have a sense of loyalty and unity toward this state.

Taking into consideration that Georgia during the period of post-communist development witnessed strong ethnic tensions, which in two cases resulted in factual territorial disintegration (Aphasia and South Ossetia), every new activated ethnic factors willy-nilly don't play positive role in formation positive attitudes toward ethnic minorities. Compactly settled ethnic minorities (the case of dispersedly settled minorities is quite different) integration level in whole public political space is very low. They take practically no participation in creation of political institutions and state building process. In Georgia on the juridical level the formal side of civil equality is guaranteed and the state is a part of the entire fundamental international legal instrument that provides the protection of human rights. However, it is the fact that only formalized juridical equality cannot guarantee active civil activity and integration. One of the obstacles of full integration is ethno-nationalist tendencies and mythologies existing in the imagination of the most of population. Ethno-nationalist tendencies are strong not only among ethnic Georgians, but also among non ethnic Georgians too (maybe even much stronger among non ethnic Georgians) ${ }^{12}$ (Dundua, Abashidze, 2009).

There are some problems in terms of religious tolerance too. In the last periods several facts of confrontation between Muslim Georgians and orthodox Georgians on the grounds of religion were in the spotlight of many international organizations. Accordingly, these facts were reflected in the reports of international organization made about religious tolerance in Georgia.

For example it is sufficient to recall the controversy surrounding the dismantling of the minaret in 2013 in the village of Chela.

Taking all this in consideration, for strengthening sense of tolerance the Georgian Orthodox Church often uses the examples of the greatest king in the history of Georgia, David the Builder, who on one hand was the powerful and

${ }^{12}$ Dundua, S. Abashidze, Z, (2009), Ethnic and Religious Identities and Civic Integration Issues in Georgia, "Intelekti",Tbilisi, (in Georgian), p. 53 
strong defender of the unity of Georgia and orthodoxy; on the other hand he has also shown the rarest examples of religious tolerance. In XI-XII century's world history (and not only these century's history) his, as statesmen's such a high activity on direction of religious tolerance was a seldom fact for the world history.

"David Agmashenebeli (David the Builder) with the help of God could make our motherland the dream country for all Georgians in all times. But this has not prevented Muslims, Jews, Armenians or other ethnic and religious minorities to live peacefully near each other in David's Georgia.... Exactly because of our heroic and tolerant nature (despite the endless wars and contradictions) Georgians were always respected in the political circles of Arabs, Persians, Mongolians, Ottomans"(Easter Epistle of Patriarch, 2005) - is said in the 2005 Easter Epistle of Patriarch.

3. Government, as an example for ordinary citizens. Our dependence on the Lord although is individual, but for society it has always had a great importance the belief or unbelief of government. People always respect and love worthy and modest lieder. That is why in the epistles of Patriarch there are frequent references to the kings of Georgia, who were distinguished by their personal traits.

\section{POLITICS OF "MEMORY CONSTRUCTION" IN CURRENT AGENDA}

Interest in memory studies increased in the wake of WWII and Holocaust. Additionally, when the soviet system collapsed it became another focal point, which stimulates research in this field. Furthermore, "memory boom" turn into a commonly used expression. The reason is simple: after the collapse of the soviet empire, former soviet republics started building their statehood. Moreover, the consolidation of the nation around new ideals and formation of new identities, which would confront to the soviet one, made by the soviet system, was the main challenge of this process. While creating new collective memory politicians reinterpreted their national histories, they re-write history textbooks, invented new heroes and enemies, established ceremonies etc. Remembering and forgetting become general trends of politics of memory accordingly.

From the point of view of social constructionist theory, both identity and memory should be analyzed as a dynamic process, and as a result, society receives changed values, goals and interests. Collective memory is an indicator of how society perceives "self" and "others", which themselves influence priorities and the decisions of society. Involving history in the political discourse we can discuss about "official politics of memory", which uses different strategies forming public opinion about historical events. 
After the Rose Revolution 2003 in Georgia, the new government that aimed at building the "new Georgia," implementing radical changes in many key spheres, including institutions, re-addressing the totalitarian past, faced number of problematic manifestations in political and cultural life in this post-Soviet country. While the new institutions were established and the old ones were reformed, for the renovation of the state system, it was essential to set relevant boundaries with the pre- Rose Revolution state system. This process can be evaluated as leading toward state nationalism.

An evaluation of the first decade of independence of country, (1991-2003) especially Eduard Shevardnadze's governance (1992-2003), was negative; Georgia was defined as a "failed state" with corrupt officials, and undeveloped institutions. The new government faced challenges to build a new state with modern citizens free from old habits and stereotypes, "because Georgia never had strong statehood with real state attributes." "13(Mikheil Saakashvili's summarizing speech) This attitude was notable in political discourse, although the main marker in recruiting state officials were youth generation free from soviet experience and complexes, equipped with fresh ideas, that was not common for the former governors. ${ }^{14}$ (Mikheil Saakashvili's Public Appearance at George Washington University).

Analyzing the politics of memory, symbolism is the most notable attitude and that is why President Mikheil Saakashvili used commemorative ceremonies continuously. First case of recall past was realized at the beginning of his presidency, when President Saaakashvili took the oath to Georgia on the tomb of King David the Builder, "Today Georgia is split and humiliated. We should unite to restore Georgia's territorial integrity. Georgia has existed and will exist. Georgia will become a united strong country," ${ }^{15}$ (Mikheil Saakashvili's Speech at the Inauguration Ceremony) said the President on the tomb of the king who united dismembered country, liberated from enemies in the XI century and his reign assumed as a basis to the Golden age of Georgia in the XII Century.

National flag, anthem and emblem have changed for very soon and St. George's Statue, a fighter against a dragon, as a representation of the new government's character, set on the main- liberty square of Tbilisi. Moving of the remains of a Georgian national hero Kakutsa Cholokashvili who fought against

\footnotetext{
${ }^{13}$ Mikheil Saakashvili's summarizng speech (26.05.2005), http://president.gov.ge/ge/PressOffice/ News/SpeechesAndStatements? $\mathrm{p}=3770 \& \mathrm{i}=2$, accessed 04.09.2011.

${ }^{14}$ Mikheil Saakashvili's Public Appearance at George Washington University, (23.02. 2004) http://president.gov.ge/ge/PressOffice/News/SpeechesAndStatements?p=2960\&i=1 accessed 02.04.2011.

${ }^{15}$ Mikheil Saakashvili's Speech at the Inauguration Ceremony (25.01.2004) http://president.gov. ge/ge/President/Inauguration, accessed 02.04.2011
} 
Tsarist Russia and was persecuted from the country, was declared as a national holiday and such commemoration rituals became part of social life.

Appealing on heroic past of nation was accepted as motivator of contemporaneity. Even the contemporary "heroes" become visible in speeches of officials, whose shared character of "heroism" was declared to be patriotism, professionalism and aspiration of being good citizens and as a rule, they were politicians, doctors, teachers, solders etc. The purpose was to show that the dream came true, and Georgia was changing.

According to Hobsbaum, during the transformation process, history has significant meaning, because of the need to invent new ideals to connect the society. These new ideals will replace the destroyed ones..$^{16}$ (Hobsbaum, 1983). This tendency is notable in the Georgian case, when historical heroes were used to consolidate the nation to build statehood after 70 years of soviet dependence and civil war that divided nation. The names of great Georgian kings, their challenges and success, dominated the political discourse. However, there were also mentioned enemies and traitors, who caused dark ages in history of Georgia, and examples of historical experience should become part of the national memory to consider future choices.

However, the first step in coping with the Soviet past was oriented towards overcoming the Soviet mentality. Because President Saakashvili's government aimed to normalize relations with the Russian Federation, experience of Georgian-Russian alliance was evaluated quite neutral formula and leaned to forget the worst cases of this relation. According to the official discourse of Georgian politicians there were some issues from Georgian-Russian relation in the political agenda that needed to be solved e.g. 200 years of dislocation of the Russian military forces in Georgia, question of Abkhazia and South Ossetia, but according to the view of Georgian politicians "now it is time to corporate as equal partners and everyone should realize that imperial relation never would come back". ${ }^{17}$ (Mikheil Saakashvili's Public Appearance on Georgian Independence Day Parade).

However, a memory strategy modified and became oriented to victimization of the "self" since 2006, when Georgian citizens were deported from the Russian Federation. The Russian-Georgian war in 2008 was a final point since relations between these countries become worst. Current strategies of memory could be associated with politics of victimization and creation of the collective memory

\footnotetext{
${ }^{16}$ Hobsbawm E, (1983) "Introduction: Inventing Traditions", in the Invention of Tradition, ed. Eric Hobsbawm and Terence Ranger (Cambridge: Cambridge University Press, pp 12

${ }^{17}$ Mikheil Saakashvili's Public Appearance on Georgian Independence Day Parade, (26.05 2005). http://president.gov.ge/ge/PressOffice/News/SpeechesAndStatements?p=2760\&i=3, accessed 05.06.2012.
} 
of "victim" prioritized as a national security issue.

In the political discourse, terms such as "occupation", "occupant", "repression" etc were prevalent. The construction of collective memory about Soviet repression was justified by the real threat coming from the North, and it was essential to be realized the cost for being part of Soviet Empire for 70 years ${ }^{18}$ (Rukhadze, 2010). The historical narrative that was formulated after the 2008 August war can be evaluated as hegemonic, which was oriented to replace myths on soviet system existing in the Georgian society.

Starting date of Russian occupation of Georgia declared not invasion of red army in Tbilisi in 1921, but 1783 when representatives of east Georgian kingdom of Kartli-Kakheti and Russian empire singed "Georgirvski Treaty". According this treaty Georgia declared as a protectorate of Russia and every new Georgian monarch would require the confirmation and investiture of the Russian tsar. In 1918, Georgia managed to become independence from Russian influence; however in 1921 XI soviet army re- established Russian governance in the country.

Creation of "memory sites" was a project that aimed to construct memory of occupation of 200 years. The first realization of this idea was the "Museum of Occupation", that was established in 2006 to commemorate an experience of repressions and resistance. President Saakashvili stated at the opening ceremony:

"This museum is dedicated to Kakutsa Cholokashvili and his brothers in arms; this museum is dedicated to the underground organizations created in this period. This museum is dedicated to the clergy, almost destroyed in this age. This museum is dedicated to a Georgian officer; this museum is dedicated to my grandfather Nikusha Tsereteli, who was exiled to Siberia".

This site of memory could be analyzed, as a case of hegemonic historical narrative, as far as museum's name express how exhibitions will present the Soviet governance. Museum of Occupation in Georgia has one exception that is not characterized for its Eastern European analogies; in this case Rose Revolution as an event, is the part of the exhibition, as an example when does Georgia started to liberate from the soviet mentality.

After the war in August, the question of overcoming of Soviet heritage became actual. One of the important aspects was a statue of Stalin in Gori, a birth place of Joseph Stalin. Symbolically, Gori was bombed by the Russian troops in August 2008. Discussion about how to overcome Stalin's memory and which way was the best for realization, became the most debatable topic in Georgia. According to the government's view, it was essential to remove the statue of the occupant. However, from another point of view, dismantling of the statue was

${ }^{18}$ Rukhadze V. (2010). Collective Memory, 24 saati (newspaper 24 hours),accessed 05.06.2012 
not an efficient way of overcoming the Soviet past; it should be kept as a tourist sightseeing, however, myths on Stalin's kindness should be removed from the mentality of people, because Stalin as an icon is still admired but more as a patriotic symbol than a political model. ${ }^{19}$

This discussion unexpectedly had finished by removing the statue from the Gori central square to the Museum of Stalin at midnight. The Ministry of Culture of Georgia aimed to set a new "memory site" on the pedestal of Stalin's statue, that would be described the Russian aggression, but these steps were never implemented.

Another question was how to evaluate WWII and its participants. According to the new narrative of the Georgian history, Soviet Russia occupied Georgia in 1921 and people in service of the Empire were part of the system. Should the Soviet soldiers to be evaluated as heroes or not, is it essential to keep their monuments in Georgia; these were the challenges faced by the Georgian society. However, there was no place for this type of heroes in Georgian narrative. Even which date of winning WWII should Georgians celebrate was under question, 9 may as an end of Great Patriotic War or 8 may - for WWII. This question have associated with the choice of foreign orientation, 9 may was evaluated as returning in Russian orbit, 8 may as the mark of European one, was chosen by the government of Georgia.

Another case of construction of hegemonic historical narrative was establishing a truth commission initiated by President Saakashvili. The commission aimed to prepare rapport on the 200 years of the Russian occupation of Georgia. This decision was evaluated as an official interpretation of history that was unacceptable for the society, aiming at overcoming the totalitarian heritage. Furthermore, this decision was evaluated same type as President Dmitri Medvedev's one, aimed to establish historical commission working against falsification of Soviet history. (According to this commission, Georgia was one of the sources of the falsification of Soviet of history). (Комиссии при Президенте Российской Федерации по противодействию попыткам фальсификации истории в ущерб интересам России 15.05.2009). This commission prepared

\footnotetext{
${ }^{19}$ According to the survey conducted by the Carnegie Endowment, high proportion of Georgians (45 $\%)$ has a positive attitude toward Stalin. Even in Armenia and Azerbaijan, where the mythologized emotional connection to Stalin is much weaker than in Russia or Georgia, Stalin wins a fairly high approval rating. Interestingly, attitudes toward Russia among Georgian respondents do not appear to strongly correlate with their opinions of Stalin. Views of Stalin are less positive among respondents who consider Russia to be Georgia's main enemy than among the rest of the population as a whole - but the variations in opinion are not so marked as to suggest that attitudes toward Stalin depend on sympathy or antipathy for Russia. Lipman M, Gudkov L, Bakradze L, (2013). The Stalin puzzle: deciphering post-Soviet public opinion. Carnegie Endowment for International Peace. pp .47-54
} 
a final rapport but it has not been published yet. (Georgian Trust Commission finished working on the question of 200 years of Russian Occupation of Georgia. 14.01.11).

The low of lustration was one of the important and politically inspired questions from the 1990s. None of the Georgian presidents decided to receive that law. First president of Georgia Zviad Gamsakhurdia rejected this regulation because of the threat of losing popularity. During Eduard Shevardnadze's time of presidency declared the willingness of lustration after the terrorists attacked president and former KGB officials were charged for this crime.

Two times was initiated this question after Rose Revolution, only in 2011 did the Georgian Parliament approved the so-called "Freedom Charter" banning the use of Soviet symbols. The Charter also prohibits Soviet-era Communist party, and national security functionaries from holding official posts in parliament, the government and the Security Council, etc ${ }^{20}$ (Charter of Freedom. Georgia). On the one hand, it was symbolic gesture; however the main aim of this Charter was to prevent certain collaborators from the politics. "There are [some figures] who were close collaborators with the KGB and they are very active politically are [still] working for Moscow. Moreover, we know it. In addition, it is very important for me to stop their movement to power" declared author of the low Ghia Tortladze." 21 (Georgia mulls banning ex-KGB members from public office). This law underlined that officials of Georgia tried to draw a line under Georgia's Soviet past once and for all.

Georgian scientists and politicians often indicate that the way of developments gone by the Eastern European countries was determined by their choice to overcome Soviet past from the 1990s. However, it was impossible in Georgia. First obstacle was not full archives that were exported to Russia in the 1988. One year later, fire destroyed files left in Tbilisi. Only $20 \%$ of personal data are available now in the archive. Another barrier was the 20 year that was gone from the collapse of Soviet Union. The question was how reasonable it was to renovate forgotten hurts, while only very few part of the former officials are still working in state structures.

Summarizing official memory politics in 2003-2012 one can conclude that politics of memory is the part of political agenda and politically is motivated. Remembering heroic past for restoration of state building and consolidation of citizens was a general trend until 2006. After the deterioration of the GeorgianRussian relations, an experience of resistance became one of the acceptable tendencies. And politics of memory become integral part of national security.

${ }^{20}$ Charter of Freedom. Georgia, 31.05.2011

${ }^{21}$ Georgia mulls banning ex-KGB members from public office (26.10. 2009). BBC News http:// news.bbc.co.uk/2/hi/europe/8380250.stm, accessed 12.07. 2013 


\section{CONCLUSION}

So, speaking about memory politics in Georgia we can outline some main aspects:

- After dismantling Soviet Union, Georgia, like other post-Soviet republics, was involved in the process of revaluation of past. Although the priorities and the rates of this process differed from eastern European countries' cases. Baltic States began this process from the very first days of the collapse of Soviet system. The Soviet past was estimated and the lustration process was carried out. In Georgia the comprehensive assessment of Soviet period has not been made. This process was limited to the declaration of the process of "sovetization" as occupation (as on the scientific, as well as on the legislative levels), topple of the monuments, changing of the textbooks of history and so on.

- Despite the beginning of the process of revaluation of the past, it is impossible to speak about the existence of a coherent revaluation politics during the 90yars. During this period, the beginning of the new policy has been largely due to changes in priorities.

- On one hand it seems like that Orthodox Church of Georgia has it's "own" memory politics, independently from the state, but on the other hand in virtually every step made in this direction high level representatives of Orthodox Church of Georgia cites the state and the government as essential supporting power. Without state support any success in this direction is incredible.

\section{REFERENCES}

Charter of Freedom (31.05.2011), Georgia. \# 4717

Сталин И.Б., (1953) Марксизм и национальный вопрос.//Сочинения. Тбилиси

Davies N. (1996) Europe, a History, Oxford University Press.

Dundua, S. Abashidze, Z, (2009), Ethnic and Religious Identities and Civic Integration Issues in Georgia, "Intelekti”, Tbilisi, (in Georgian).

Easter Epistle of Patriarch 2005, ttp://www.orthodoxy.ge/patriarqi/epistoleebi/ saagdgomo 2005.htm. seen in 15 April, 2014.

Elshtain J. B., (April 2009) Religion and Democracy, Journal of Democracy, Volume 20, Number 2

Georgia mulls banning ex-KGB members from public office (26.10. 2009). BBC

News http://news.bbc.co.uk/2/hi/europe/8380250.stm , accessed 12.07. 2013

Georgian Trust Commission finished working on the question of 200 years of 
Russian Occupation of Georgia. 24 Saati. (Newspaper 24 hours). 14.01.11. http://24saati.ge/index.php/category/news/2011-01-14/13129.htm 1 , accessed 10.07. 2013.

Hobsbawm E, (1983) "Introduction: Inventing Traditions", in the Invention of Tradition, ed. Eric Hobsbawm and Terence Ranger (Cambridge: Cambridge University Press.

Комиссии при Президенте Российской Федерации по противодействию попыткам фальсификации истории в ущерб интересам России (15.05.2009), \#549

Коппитерс Б. (1999) «Этнофедерализм и политика в области строительства гражданского государства. (Поиски альтернативов для Грузии и Абхазии) Практика федерализма (Общая редакция Б. Коппитерс, Д.Дарчиашвили, Н. Акаба) Весь мир, Москва.

Lipman M, Gudkov L, Bakradze L, (2013). The Stalin puzzle: deciphering postSoviet public opinion. Carnegie Endowment for International Peace.

Merchule G. (2000) Life and Citizenship of Grigol Khantsteli". Tbilisi, (in Georgian) (p.12)

Mikheil Saakashvili's Public Appearance at George Washington University, (23.02. 2004) http://president.gov.ge/ge/PressOffice/News/ SpeechesAndStatements? $=2960 \& \mathrm{i}=1$ accessed 02.04.2011.

Mikheil Saakashvili's summarizng speech (26.05.2005), http://president.gov. ge/ge/PressOffice/News/SpeechesAndStatements? $\mathrm{p}=3770 \& \mathrm{i}=2$, accessed 04.09.2011.

Mikheil Saakashvili's Public Appearance on Georgian Independence Day Parade, (26.05 2005). http://president.gov.ge/ge/PressOffice/News/ SpeechesAndStatements? $\mathrm{p}=2760 \& \mathrm{i}=3$, accessed 05.06.2012.

Mikheil Saakashvili's Speech at the Inauguration Ceremony (25.01.2004) http:// president.gov.ge/ge/President/Inauguration, accessed 02.04.2011.

Pipes R. (1954) the Formation of the Soviet Union: Communism and Nationalism 1917-1923, Harvard University Press.

Rukhadze V. (2010). Collective Memory, 24 saati (newspaper 24 hours),accessed 05.06.2012

Sakva R. (1989) Soviet Politics, an introduction, Rutledge, London and New York.

Sunny R. (2001), State-building and nation-making / The Russian Revolution, edited by Martin A. Miler, Blackwell Publisher. 